\title{
Nitrogen fixation by Trichodesmium spp. in the Central and Northern Great Barrier Reef Lagoon: relative importance of the fixed-nitrogen load
}

\author{
P. R. F. Bell ${ }^{1, *}$, I. Elmetri ${ }^{1}$, P. Uwins ${ }^{2}$ \\ ${ }^{1}$ Low Isles Research Station and Department of Chemical Engineering, University of Queensland, Brisbane 4072, Australia \\ ${ }^{2}$ Centre for Microscopy and Microanalysis, University of Queensland, Brisbane 4072, Australia
}

\begin{abstract}
Studies in the Great Barrier Reef Lagoon (GBRL) show that Trichodesmium (Oscillatoria) spp. fix significant amounts of atmospheric nitrogen and that the loads of 'new' nitrogen introduced by Trichodesmium spp. are at least of the same order as those entering via riverine discharge. The elevated growth of other genera of phytoplankton and hence eutrophication in some sections of the GBRL could now be largely driven by the in situ production of this 'new' nitrogen. Trichodesmium is more prolific in the Central GBRL than in the Northern GBRL and there is evidence that the concentrations of Trichodesmium spp. have increased since the 1928-29 Great Barrier Reef Expedition to Low Isles. It is hypothesised that this increase has resulted from increases in river borne nutrients that would promote $\mathrm{N}$ fixation (e.g. phosphorus, iron and dissolved organic matter). It is estimated that the loads of such nutrients have increased several fold since the development of the coastal catchments of Queensland.
\end{abstract}

KEY WORDS: Trichodesmium · Nitrogen fixation · Eutrophication · Great Barrier Reef

\section{INTRODUCTION}

The Great Barrier Reef Lagoon (GBRL) in this study refers to the shallow $(<40 \mathrm{~m})$ water body bounded by the mainland and the outer reef matrix of the Great Barrier Reef (GBR) (Fig. 1). Trichodesmium spp. often dominate the microplankton $(>20 \mu \mathrm{m})$ community in the Central (off Townsville) and Northern (off Port Douglas/Low Isles) GBRL (Marshall 1933, Revelante \& Gilmartin 1982, Elmetri 1993). Trichodesmium blooms in the region have been implicated in direct smothering of corals and the promotion of the bioavailability of heavy metals (Endean 1976, Jones 1987, 1992). Various workers have shown that Trichodesmium spp. fix atmospheric nitrogen (Goering et al. 1966, Carpenter \& McCarthy 1975). Carpenter \& Price (1977), using the acetylene reduction method (a sensitive measure of nitrogenase activity and hence $\mathrm{N}$ fixation), observed average $\mathrm{N}$ fixation rates of $0.077 \mathrm{pg} \mathrm{N}$ cell $^{-1} \mathrm{~h}^{-1}$ in the Caribbean Sea and $0.033 \mathrm{pg} \mathrm{N}$ cell $^{-1} \mathrm{~h}^{-1}$ in the Sargasso Sea. Data of Carpenter \& McCarthy (1975) for the west-

•E-mail: p.bell@mailbox.uq.edu.au ern Sargasso Sea show an average $\mathrm{N}$ fixation rate of $0.069 \mathrm{pg} \mathrm{N} \mathrm{cell}^{-1} \mathrm{~h}^{-1}$. They conclude that $\mathrm{N}$ fixation is the main source of $\mathrm{N}$ for $T$. thiebautii, the most abundant of the 3 Trichodesmium species identified in their Caribbean studies. T. thiebautii also occurs in the GBRL but $T$. erythraeum is often dominant (Revelante \& Gilmartin 1982). Bryceson \& Fay (1981) have measured the acetylene reduction rate for $T$. erythraeum collected in the coastal waters off Tanzania (East Africa). From their results the mean value of the $\mathrm{N}$ fixation rate per cell is, assuming the conversion factor of $4: 1$ and 100 cells per trichome (filament) (Capone 1993, Carpenter \& Capone 1992), $0.095 \mathrm{pg} \mathrm{N}$ cell ${ }^{-1} \mathrm{~h}^{-1}$, which is in quite good agreement with the above-mentioned values for T. thiebautii. Higher values have been recorded for blooms in some coastal waters; Carpenter \& Capone (1992) suggest that a typical value is $1.5 \mathrm{pg} \mathrm{N} \mathrm{cell}^{-1} \mathrm{~h}^{-1}$.

Results from acetylene reduction studies with Trichodesmium erythraeum in the Northern and Central GBRL equate to (assuming a 4:1 conversion ratio, Capone 1993) a mean $\mathrm{N}$ fixation rate of $0.08 \mathrm{pg} \mathrm{N}$ cell $^{-1}$ $\mathrm{h}^{-1}$ (Bell et al. 1993). This result is in good agreement with the results from several of the above-mentioned 


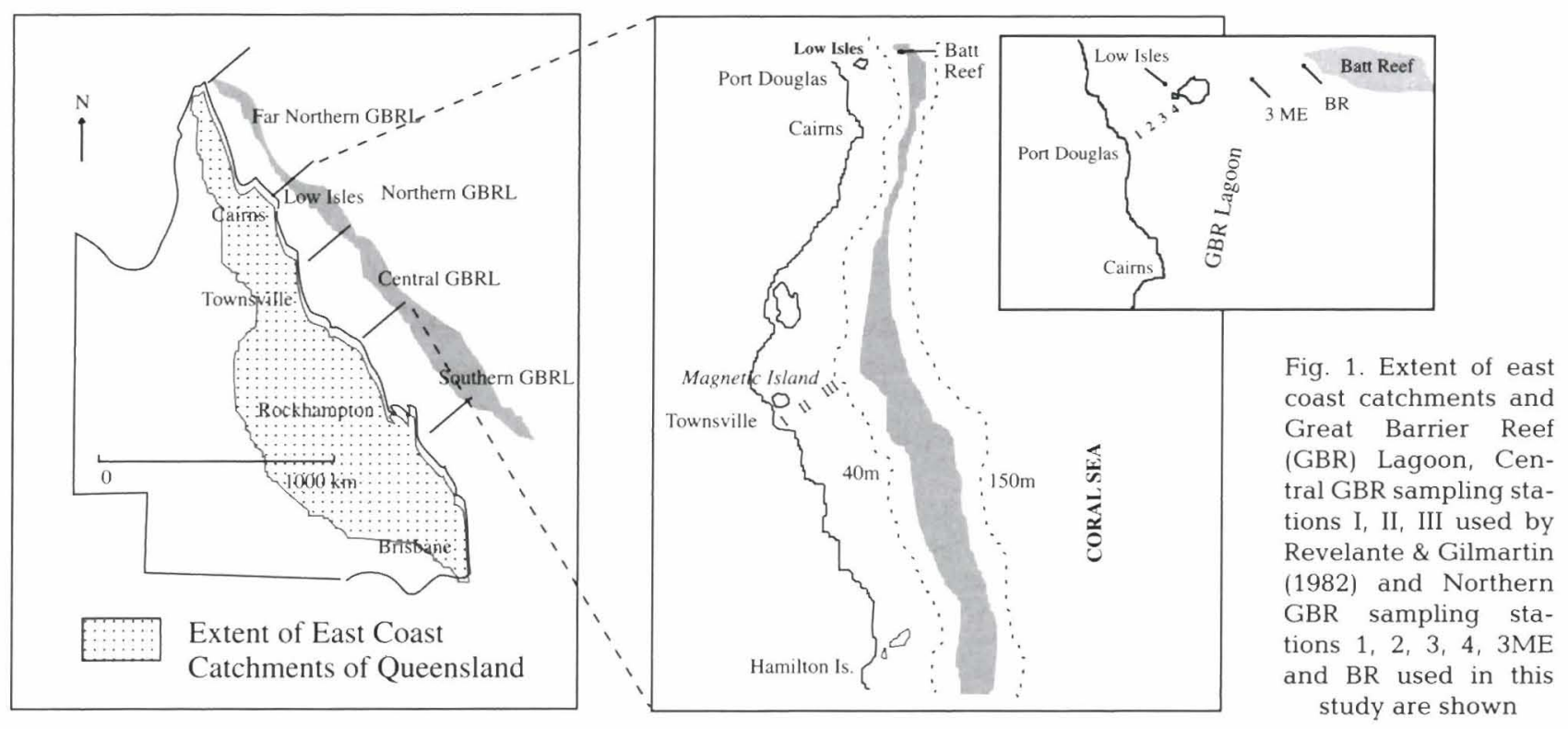

studies. The available data on the standing crop of Trichodesmium in the GBRL are quite limited but these data do suggest that relatively high concentrations of Trichodesmium spp. occur regularly, and hence Trichodesmium spp. have the potential to introduce large amounts of 'new' nitrogen into the GBRL. The work reported below provides additional quantitative information on the rates of $\mathrm{N}$ fixation of Trichodesmium in the Northern GBRL and standing crop of Trichodesmium spp. in the Northern and Central GBRL. These data are used to estimate the loads of 'new' nitrogen introduced to the Northern and Central GBRL by Trichodesmium

\section{MATERIALS AND METHODS}

Variation in standing crop of Trichodesmium at Low Isles. Trichodesmium concentrations were determined in surface samples $(0.5 \mathrm{~m})$ collected every 1 to 2 wk during 1992-93 at a sampling station located 3 miles east (Stn 3ME) off Low Isles, the same station used by the 1928-29 Expedition (Marshall 1933, Orr 1933). In addition to the regular sampling, 2 bloom events (30-31 October 1995 and 10 October 1997) were sampled to determine the cross-shelf and depth variation of the Trichodesmium standing crop. Depth samples were collected at 4 sampling stations (Stns 1 to 4 ) on a transect between Port Douglas and Low Isles, and also at Stn 3ME and at Batt Reef (Stn BR), using a 101 Niskin bottle. Trichodesmium concentrations were determined by filtering a preserved (Lugol's solution) $200 \mathrm{ml}$ sample through a graduated membrane filter ( $0.45 \mu \mathrm{m}$ pore size) and counting the trichomes (filaments) retained on the filter using a normal com- pound/binocular microscope $(\times 100$ magnification $)$. This filtering method provides equivalent counts to the Utermohl settling method (Elmetri 1993) but is relatively quick in comparison with that method and does not require the use of an inverted microscope.

Variation in standing crop of Trichodesmium in Cleveland Bay (off Townsville). Stn I in Cleveland Bay (off Townsville) was occupied at approximately weekly intervals from September 1993 to January 1994. Water samples were collected from $0.5 \mathrm{~m}$ depth using a $10 \mathrm{l}$ Niskin bottle. Several litres were filtered $(0.45 \mu \mathrm{m}$ pore size glass fibre filter) on-site for subsequent chlorophyll $a$ analysis. The filters were stored in a cooler and frozen within $1 \mathrm{~h}$ of collection. Two $250 \mathrm{ml}$ samples were preserved on-site with Lugol's solution and were later analysed for Trichodesmium spp. using the above-mentioned filter method and for the other principal genera in the microphytoplankton using Utermöhl's inverted microscope method.

Nitrogen fixation studies - Low Isles. Four series of experiments were completed. Series 1 and 2 were of $1 \mathrm{~d}$ duration only. For Series 1 and 2, water samples were collected from $1 \mathrm{~m}$ depth with a depth sampler from a station located $1 \mathrm{~km}$ north of Low Isles. Series 3 was undertaken over a $4 \mathrm{~d}$ period during a prolonged bloom event; samples were collected as for Series 1 and 2, from the same location. Series 4 samples were collected from the Anchorage at Low Isles, on 2 days immediately following Series 3. All water samples were collected at approximately 09:00 $\mathrm{h}$ and the incubations were generally conducted between 10:00 and 14:00 h.

The acetylene reduction method was used to estimate the N fixation rates (Stewart \& Alexander 1971, Mague et al. 1974, Carpenter \& McCarthy 1975, Carpenter \& Price 1977, Bryceson \& Fay 1981, Capone 
1993). The samples were concentrated by gently filtering off most of the water through a $20 \mu \mathrm{m}$ glass fibre filter. Colonies, both radial (R) and longitudinal (L), and individual trichomes ( $\mathrm{T}$ ) from the concentrate were gently pipetted from the concentrate and washed in filtered $(0.45 \mu \mathrm{m})$ seawater and then transferred to filtered seawater contained in widemouth serum bottles (approximately 80\%) full. Each bottle was sealed with a longskirted red-silicone rubber serum stopper. Scrubbed acetylene, which had been freshly prepared on-site from calcium carbide, was injected into each bottle

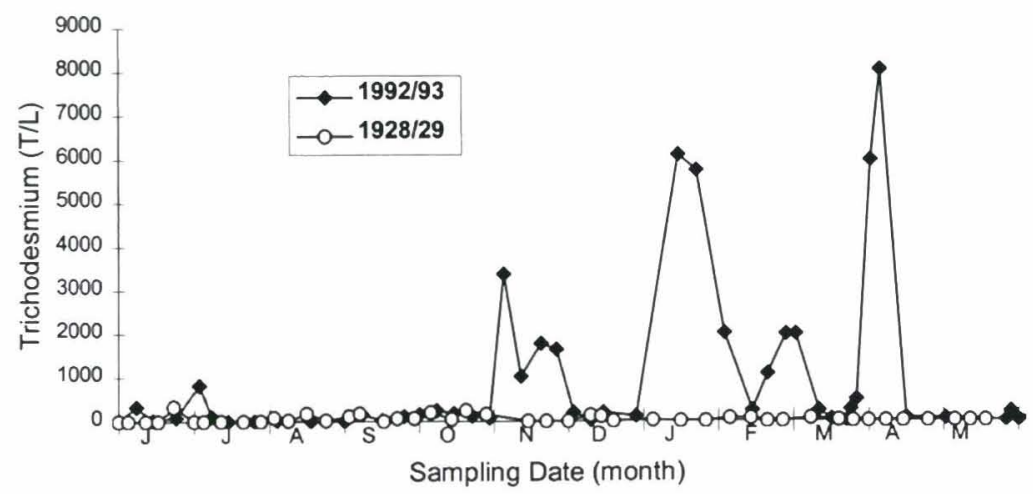

Fig. 2. Comparison of seasonal variation of Trichodesmium spp. (trichomes $\mathrm{l}^{-1}$ ) at Stn 3ME near Low Isles in 1928-29 (Marshall 1933) and 1992-93 using a gas-tight syringe to give an initial concentration of acetylene of at least $15 \%$.

A gas phase sample was extracted from each bottle at zero time using a gas-tight syringe and was analysed immediately for ethylene concentration using a Photovac 10 s plus portable GC fitted with a photoionisation detector (PID). The bottles were incubated indoors at $25 \pm 1.5^{\circ} \mathrm{C}$ for 2 to $3 \mathrm{~h}$ in natural shaded sunlight. Gas samples were then extracted and analysed for ethylene concentration on the GC. The gas phases of several control blanks, i.e. bottles containing filtered sea water with added acetylene but with no added Trichodesmium, were also analysed at zero time and after the incubation period in order to determine the background ethylene concentration in the absence of any acetylene consumption by Trichodesmium. The bottle contents were gently removed at the end of each experiment and the average number of trichomes per colony and number of cells per trichome were determined by microscopic examination with magnifications up to $\times 200$. A conversion factor of $4: 1$ was assumed in converting the ethylene production rates to $\mathrm{N}$ fixation rates (Capone 1993).

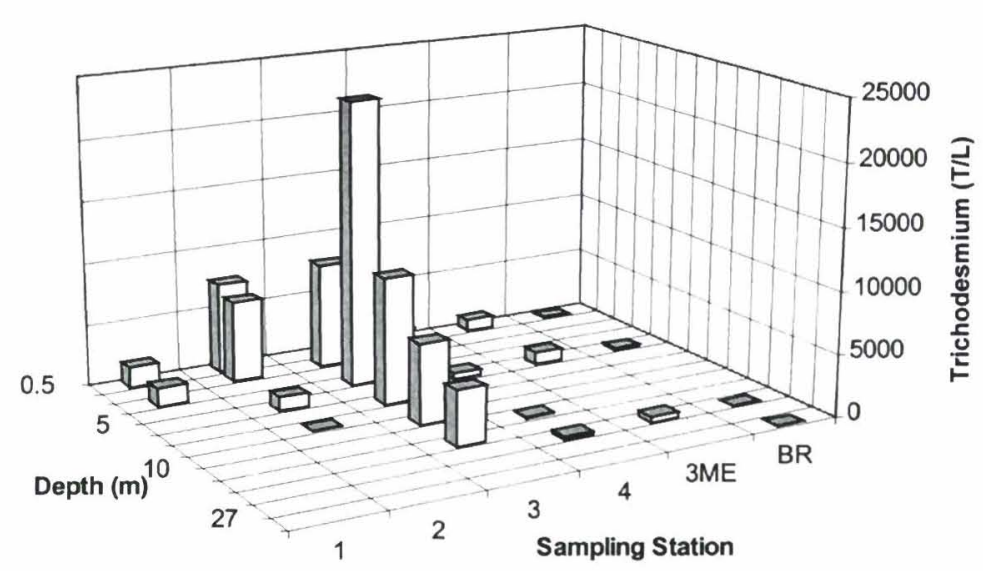

Fig. 3. Cross-shelf depth distribution of Trichodesmium spp. (trichomes $1^{-1}$ ) on 30 October 1995 on a transect between Port Douglas and Batt Reef

\section{RESULTS}

\section{Standing crop of Trichodesmium at Low Isles and in Cleveland Bay}

The seasonal variation of Trichodesmium spp. at Stn 3ME near to Low Isles during 1992-93 was compared with the corresponding data collected by Marshall (1933) in 1928-29. This comparison suggests that there has been a significant increase in the standing crop of Trichodesmium spp. since 1928-29 (Fig. 2). However, the difference is probably not as great as is indicated. The basic reason for this is that the centrifuge separation method used by Marshall tends to underestimate the concentration of Trichodesmium spp. in the surface samples (Elmetri 1993). Results from a number of comparative studies using both separation methods with samples collected between February and April 1993 show that the centrifuge method underestimates the average number of trichomes $(\mathrm{T})$ by about $100 \%$. Applying this correction factor to the 1928-29 data gives an annual mean of about $100 \mathrm{~T} \mathrm{l}^{-1}$, which is still an order of magnitude less than the 1992-93 mean value of $1000 \mathrm{~T} \mathrm{l}^{-1}$.

During 2 bloom events in the Low Isles region, Trichodesmium was distributed across much of the lagoon and to depths greater than $20 \mathrm{~m}$ (Figs. 3 \& 4). At some stations the highest concentrations were at depth and at others at the surface.

The concentrations of Trichodesmium spp., diatoms (pennate + centric) and chlorophyll a in Cleveland Bay during the period from September 1993 to January 1994 are shown in Fig. 5. The results suggest a cyclical but out of phase pattern for the occurrences of Trichodesmium and diatoms. 


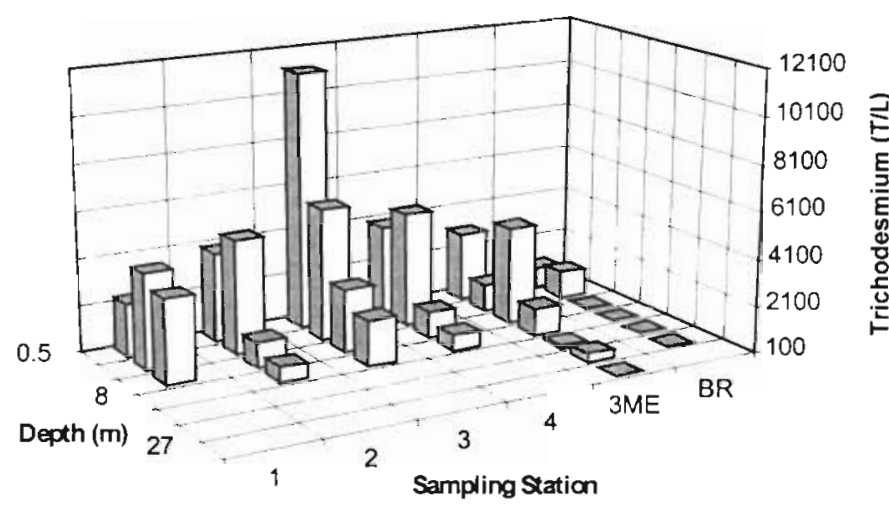

Fig. 4. Cross-shelf depth distribution of Trichodesmium spp. (trichomes $1^{-1}$ ) on 10 October 1997 on a transect between Port Douglas and Batt Reef

\section{Colony size and $\mathbf{N}$ fixation rates}

Trichodesmium thiebautii dominated the 4 series of $\mathrm{N}$ fixation experiments. The average number of trichomes per radial (R) colony was 157 and per longitudinal (L) colony was 21 and the average number of cells per trichome was 59 (Table 1). Although some trichomes contained many more cells (maximum number of cells per trichome was 340), many were quite short, which is consistent with an actively growing population.

The average $\mathrm{N}$ fixation rate for Trichodesmium thiebautii was $0.08 \mathrm{pg} \mathrm{N}$ cell ${ }^{-1} \mathrm{~h}^{-1}$ (Table 2), which is equivalent to the value we obtained for $T$. erythraeum in previous studies at Low Isles and Hamilton Island (Bell et al. 1993). The maximum rate $0.40 \mathrm{pg} N$ cell $^{-1} \mathrm{~h}^{-1}$ was recorded in Series 1 for an experiment containing $L$ colonies only; this sample had relatively long trichomes (average number of cells per trichome was 103; maximum number of cells per trichome was 340 ). In fact, in general, but not always, it was found that $\mathrm{L}$ colonies exhibited higher fixation rates per cell than did the $\mathrm{R}$ colonies. Two experiments in Series 3 were conducted with single trichomes only. Both of these experiments exhibited relatively low $\mathrm{N}$ fixation rates $(0.04$ and $<0.01 \mathrm{pg} \mathrm{N}$ cell ${ }^{-1} \mathrm{~h}^{-1}$ ).

\section{DISCUSSION}

\section{Standing crop of Trichodesmium at Low Isles and in the Central GBRL}

The standing crop data for Stn $3 \mathrm{ME}$ support the hypothesis that there has been a significant increase in the standing crop (and hence productivity) of Trichodesmium spp. in the Northern GBRL since 1928 29. This is consistent with the increases measured for diatoms ( $\times 4$ increase for 1992-93 annual average) and dinoflagellates $(\times 20$ increase for winter sampling) at this same sampling station (Bell \& Elmetri 1995). Such increases in concentrations of phytoplankton have been attributed to an increase in the fertility of the GBRL. It has been hypothesised that this increased fertility has resulted from the increased loads of nutrients exported from agricultural developments over the past century or so and in particular those which have occurred since the 1928-29 Expedition (Cosser 1987, Moss et al. 1992, Bell \& Elmetri 1995).

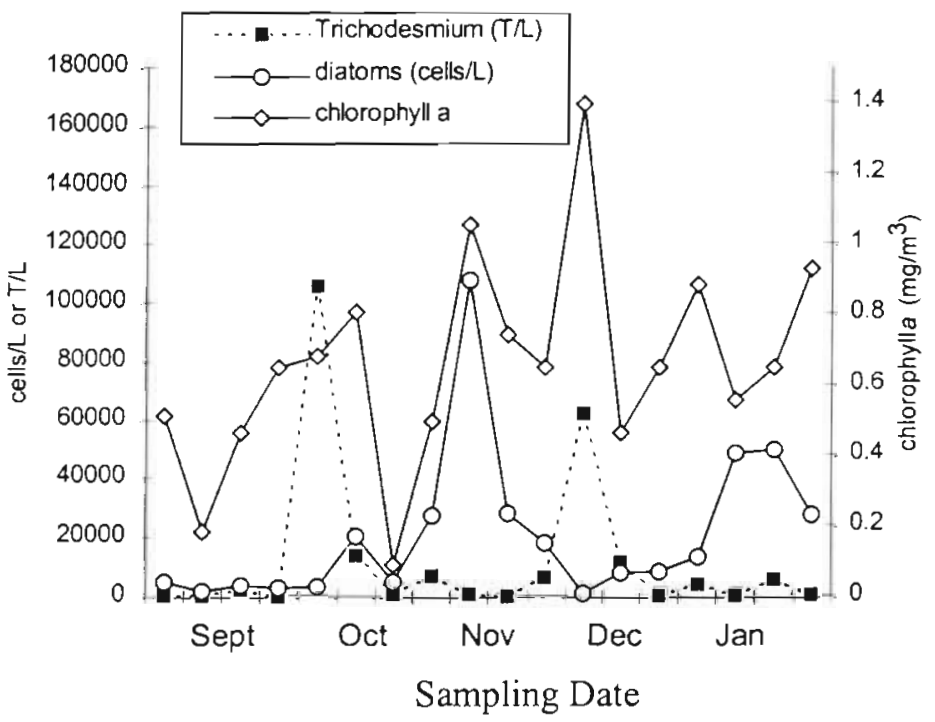

Fig. 5. Variation of Trichodesmium spp. (trichomes $\mathrm{l}^{-1}$ ), diatoms and chlorophyll a in surface samples $(0.5 \mathrm{~m})$ at Stn I in Cleveland Bay between September 1993 and January 1994

Table 1. Summary of cell counts and trichome (T) (filament) counts for radial (R) and longitudinal (L) colonies of Trichodesmium thiebautii; n: sample size of colonies or trichomes

\begin{tabular}{|ccccccc}
\hline $\begin{array}{c}\text { Average } \\
\text { trichomes per } \\
\text { R colony } \\
(\mathrm{n}=143)\end{array}$ & $\begin{array}{c}\text { Maximum } \\
\text { trichomes per } \\
\text { R colony }\end{array}$ & $\begin{array}{c}\text { Average } \\
\text { trichomes per } \\
\text { L colony } \\
(\mathrm{n}=431)\end{array}$ & $\begin{array}{c}\text { Maximum } \\
\text { trichomes per } \\
\text { L colony }\end{array}$ & $\begin{array}{c}\text { Average cells } \\
\text { per trichome } \\
(\mathrm{n}=1110)\end{array}$ & $\begin{array}{c}\text { Maximum } \\
\text { cells per } \\
\text { trichome }\end{array}$ & $\begin{array}{c}\text { Minimum } \\
\text { cells per } \\
\text { trichome }\end{array}$ \\
\hline 157 & 390 & 21 & 47 & 59 & 340 \\
\hline
\end{tabular}


Table 2. $\mathrm{N}$ fixation rates of Trichodesmium thiebautii collected near to Low Isles

\begin{tabular}{|c|c|c|c|c|}
\hline Series & Date & $\begin{array}{l}\text { No. of } \\
\text { samples }\end{array}$ & $\begin{array}{c}\text { Mean } \\
\mathrm{N} \text { fixation rate } \\
\left(\mathrm{pg} \mathrm{N}_{\text {cell }}{ }^{-1} \mathrm{~h}^{-1}\right)\end{array}$ & $\begin{array}{c}\text { Maximum } \\
\text { N fixation rate } \\
\left(\text { pg } \mathrm{N}_{\text {cell }} \mathrm{h}^{-1}\right)\end{array}$ \\
\hline 1 & 1 Nov 1994 & 5 & 0.14 & 0.40 \\
\hline 2 & 1. Dec 1994 & 8 & 0.02 & 0.05 \\
\hline 3 & 13 Jan 1995 & 4 & 0.11 & 0.31 \\
\hline 3 & 15 Jan 1995 & 6 & 0.12 & 0.13 \\
\hline 3 & $16 \mathrm{Jan} 1995$ & 4 & 0.03 & 0.08 \\
\hline 4 & $17 \operatorname{Jan} 1995$ & 7 & 0.11 & 0.16 \\
\hline 4 & $18 \operatorname{Jan} 1995$ & 3 & 0.08 & 0.13 \\
\hline \multicolumn{3}{|c|}{ Overall mean } & 0.08 & \\
\hline
\end{tabular}

mean concentration of Trichodesmium of 6000 $\mathrm{T}^{-1}$, a value 6 times the annual mean measured at Stn 3ME off Low Isles in 1992-93 and 60 times that measured in 1928-29.

\section{Cyclical patterns in growth of phytoplankton}

The results for Cleveland Bay (Fig. 5) show a cyclical pattern for the occurrence of high concentrations of Trichodesmium and diatoms, with high chlorophyll a values sometimes correlating with the Trichodesmium peaks and at other times with diatom peaks. However, the results also show that high chlorophyll a values occur when neither Trichodesmium nor

An estimated $15 \times 10^{6} \mathrm{t}$ of sediment, $77000 \mathrm{t}$ of $\mathrm{N}$ and $11000 \mathrm{t}$ of $\mathrm{P}$ are now exported annually from the coastal catchments of Queensland, i.e. some 3 to 5 times the estimated export loads from the pristine catchments prior to European development (Moss et al. 1992). Overall, most of the loads of nutrients emanate from grazing and cropping lands, with only $11 \%$ of the total coastal catchment of Queensland now being classed as pristine. Cropping lands have been identified as the main source of nutrients in the catchments bordering the Northern GBRL and most of this development has occurred since the 1928-29 Expedition (Moss et al. 1992, Bell \& Elmetri 1995). Much of the remote Far Northern Cape York region is classified as grazing land and the estimated export of nutrients from that region to the Far Northern GBRL is also of the order of 3 to 5 times the pre-European development loads. For this reason, and also due to the fact that water currents generally flow to the north from the more impacted Central-Southern region, no region of the GBRL could now be considered pristine (Bell \& Elmetri 1995).

The cross-shelf distributions of Trichodesmium during the 2 bloom events (Figs. $3 \& 4$ ), the existence of many short filaments and the measured $\mathrm{N}$ fixation rates demonstrate that Trichodesmium actively grows in the GBRL and is not simply blown in as a surface slick from the oligotrophic coral sea. This finding supports the hypothesis that the growth of Trichodesmium is linked to the input of nutrients (particularly those that promote $\mathrm{N}$ fixation, e.g. phosphorus, iron and organic matter) from the coastal catchments (Howarth et al. 1988, Rueter 1988, Bell 1991). This hypothesis is further supported by the occurrence of relatively high concentrations of Trichodesmium in the Central GBRL (see Fig. 5), a region characterised by relatively high concentrations of dissolved reactive phosphorus, P$\mathrm{PO}_{4}$ (Revelante \& Gilmartin 1982, Bell 1991). Indeed the results for Cleveland Bay equate to a seasonal diatom concentrations are high, suggesting that other taxa (e.g. dinoflagellates and other flagellates) are responsible for the higher chlorophyll a values.

The current practice of some workers (e.g. Brodie et al. 1997) of neglecting chlorophyll a peaks over $1 \mu \mathrm{g} \mathrm{l}^{-1}$ in the assessment of annual/seasonal mean concentrations because they might be biased by the occurrence of 'episodic surface aggregations of Trichodesmium' is totally insupportable in light of these data and those of Revelante \& Gilmartin (1982) which also show that high chlorophyll a values are often due to taxa other than Trichodesmium. Such practices preclude the use of such data in comparisons with annual/seasonal means of other workers both in Australia and from around the world who have not made such adjustments to their data sets.

Our previous work (Bell \& Elmetri 1995) and the work of others (Marshall 1933, Revelante \& Gilmartin 1982) have demonstrated the importance of wind as a driving force for promoting the growth of Trichodesmium and diatoms. Generally it has been found that highest concentrations of Trichodesmium occur during prolonged calm wind ( $<10$ knots) conditions whereas the highest diatom concentrations occur during windy (>15 knots) conditions.

One possible scenario that explains these observations is that: (1) Calm weather provides the ideal physical/chemical conditions for Trichodesmium spp. (e.g. low turbidity, high light at depth, low availability of DINi. Such calm conditions would be conducive to bundle formation (which, as discussed below, appears to enhance $\mathrm{N}$ fixation) and would allow the Trichodesmium to optimise the incident light and nutrient supply through its buoyancy adjustment mechanisms. Under such calm conditions, competition for nutrients with other taxa, which tend to settle out (e.g. diatoms), would be minimised and the resultant Trichodesmium blooms would eventually form large decaying slicks. (2) With the onset of wind, the dissolved nutrients pro- 
duced by the decaying slicks (e.g. DIN and $\mathrm{P}_{-} \mathrm{PO}_{4}$; see Borstad 1978, Revelante \& Gilmartin 1982, Bell 1992) together with those released from the mixed-up sediments would provide ideal conditions for the now suspended diatoms. Even closer links could be involved, for example, Trichodesmium can probably utilise organic $\mathrm{P}$ as its sole source of $\mathrm{P}$ and appears to require an external source of vitamin $B_{12}$ (Yentsch et al. 1972, Ohki \& Fujita 1982). Such substances could well be supplied by the growth and/or during the bacterial decay of other taxa (e.g. see Yentsch 1963).

\section{Colony size and $\mathrm{N}$ fixation studies}

Previous studies (Bell et al. 1993) with Trichodesmium erythraeum at Low Isles and Hamilton Island (in the Central GBRL) found the average number of trichomes per bundle was 18 and the average number of cells per trichome was 62 . These results and those from the present study suggest an overall cell/trichome ratio of about 60 for both of the common species of Trichodesmium in the GBRL. This finding and the finding that both species had essentially the same average $\mathrm{N}$ fixation rate per cell $\left(0.08 \mathrm{pg} \mathrm{N}\right.$ cell $\left.{ }^{-1} \mathrm{~h}^{-1}\right)$ allow us to normalise the previously reported concentrations of trichomes per unit volume, initially to cells per unit volume and, finally, to the amount of nitrogen fixed per unit volume per unit time.

The range and mean value of the $\mathrm{N}$ fixation rates determined for Trichodesmium thiebautii (Table 2) are in general agreement with those found by several workers for Trichodesmium spp. in other parts of the world (Carpenter \& McCarthy 1975, Carpenter \& Price 1976, 1977, Bryceson \& Fay 1981, Carpenter \& Capone 1992). The observation that single filaments do fix atmospheric nitrogen but at a rate far less than colonies supports the findings of previous workers who have shown that 'bundleness' or colony formation increases the rate of $\mathrm{N}$ fixation but is not necessary for $\mathrm{N}$ fixation (Carpenter \& Price 1976, Saino \& Hattori 1982).

\section{Estimate of loads of fixed $\mathrm{N}$}

Various methods of calculating the input of 'new' nitrogen to the GBRL from Trichodesmium are possible. The first 2 methods (Methods 1 and 2) essentially follow that used by Carpenter \& Capone (1992) in that they are based on measured $\mathrm{N}$ fixation rates and concentrations of Trichodesmium spp. The measured average $\mathrm{N}$ fixation rate, $0.08 \mathrm{pg} \mathrm{N}$ cell $^{-1} \mathrm{~h}^{-1}$, and the measured conversion factor of 60 cells $\mathrm{T}^{-1}$ are used in the calculations below. Method 1 is based on an annual/seasonal mean concentration of Trichodes- mium (mean concentration of samples collected every 1 to $2 \mathrm{wk}$ throughout the year/season) and Method 2 is based on bloom concentrations only. Method 3 considers the amount of $\mathrm{N}$ fixation required to establish the bloom. All calculations require the specification of a mean depth of active growth. Carpenter \& Capone (1992) used $5 \mathrm{~m}$ in their calculations for a typical bloom. Such a value is supported by the data in Figs. 3 $\& 4$ and hence a $5 \mathrm{~m}$ depth of active growth is used in the following calculations.

Method 1

Using an annual average concentration of $7000 \mathrm{~T} \mathrm{l}^{-1}$ for the Central GBRL (Revelante \& Gilmartin 1982), an annual average $\mathrm{N}$ fixation time of $10 \mathrm{~h} \mathrm{~d}^{-1}$ results in an annual load of $0.61 \mathrm{t} \mathrm{N} \mathrm{km}^{-2}$ (equivalent to $0.61 \mathrm{~g} \mathrm{~N}$ $\mathrm{m}^{-2}$ ). For the Northern GBRL near to Low Isles, using an annual average concentration of $1000 \mathrm{~T} \mathrm{l}^{-1}$ (Fig. 2) and other data as for the Central GBR results in an annual load of $0.09 \mathrm{t} \mathrm{N} \mathrm{km}^{-2}$.

Furnas et al. $(1995,1997)$ used Method 1 to estimate the amount of nitrogen fixed by Trichodesmium spp. in the GBR in the Cairns region and for the Tully region of the Northern GBRL. These authors used literature values for the range of $\mathrm{N}$ fixation rates and Marshall's (1933) data for estimating the seasonal and annual mean concentration of Trichodesmium. However, their estimated loads are some 40 times too high because they misinterpreted Marshall's data; they assumed that Marshall's counts were colonies per litre and multiplied Marshall's data by their assumed value of 40 trichomes colony ${ }^{-1}$. It is clear from Marshall's text that the reported 'threads' per litre are in fact trichomes (or filaments) per litre not colonies (or bundles). As Marshall notes, each 'thread' would contain on average about 80 cells. Fig. 2 compares Marshall's actual data with our 1992-93 results. If one were to compare our data with those presented by Furnas et al. $(1995,1997)$ one would be led to the impression that not much has changed with respect to Trichodesmium standing crop since 1928-29. However, as noted above, a comparison of Marshall's data with our data suggests that a significant increase in the annual standing crop of Trichodesmium (and hence in the amount of $\mathrm{N}$ fixed annually) has occurred in the Northern GBRL since the 1928-29 Great Barrier Reef Expedition.

\section{Method 2}

This method requires both the average bloom concentration and bloom duration (Carpenter \& Capone 1992). The data of Revelante \& Gilmartin (1982) sug- 
gest for the Central GBRL a mean bloom concentration of $25000 \mathrm{~T}^{-1}$ and a bloom duration of $30 \mathrm{~d}$. The data of Revelante \& Gilmartin (1982) and our data for Low Isles suggest the occurrence of $\mathbf{4}$ blooms per year. Using an average $12 \mathrm{~h}$ period of $\mathrm{N}$ fixation per day leads to a annual 'new' nitrogen input of $0.86 \mathrm{t} \mathrm{N} \mathrm{km}{ }^{-2}$ of lagoon.

For 1993, the average bloom concentration in the Northern GBRL was about $6000 \mathrm{TJ}^{-1}$ (Fig. 2). Using this concentration, and other data as for the Central GBRL, results in an annual load for the Northern GBRL near to Low Isles of $0.21 \mathrm{t} \mathrm{N} \mathrm{km}^{-2}$.

\section{Method 3}

The first 2 methods are useful but, because they ignore the amount of fixed $\mathrm{N}$ needed to establish the standing crop of Trichodesmium, they probably significantly underestimate the amount of 'new' nitrogen fixed by Trichodesmium spp., particularly during short bloom periods. Also, Methods 1 and 2 require good estimates of the seasonal variation in the $\mathrm{N}$ fixation rates and the depth and spatial variation in such rates - such data are generally not available. Method 3 relies on the assumption that all the cellular nitrogen in the Trichodesmium is derived from $\mathrm{N}$ fixation - as was concluded by Carpenter \& Price (1977) and Carpenter \& McCarthy (1975). With this assumption and using a conservative value of measured nitrogen content, i.e. $50 \mathrm{pg} \mathrm{N}$ cell $^{-1}$ (Carpenter \& Price 1977, Carpenter \& Capone 1992), the amount of 'new' nitrogen required to establish 4 blooms, with a mean concentration in the Central GBR of $25000 \mathrm{~T} \mathrm{l}^{-1}$, is $1.5 \mathrm{t} \mathrm{N} \mathrm{km}^{-2}$. This annual load is higher than that predicted by Methods 1 and 2 but it is considered conservative because it ignores the amount of nitrogen fixed following the bloom and the losses of the standing crop, e.g. due to grazing. In fact, the estimated load from Method 2 and part of that from Method 1 should be added to that obtained by Method 3. It is important to note that if the bloom period is short then Method 2 will give a relatively small value for the amount of $\mathrm{N}$ fixed, whereas Method 3 is unaffected by the duration of the bloom.

For the Northern GBRL near to Low Isles, assuming an annual bloom concentration of $6000 \mathrm{~T}^{-1}$ and other data as for the Central GBRL, the annual load is $0.36 \mathrm{t}$ $\mathrm{N} \mathrm{km}^{-2}$.

\section{Importance of $\mathrm{N}$ fixation}

The loads of $\mathrm{N}$ introduced by Trichodesmium estimated by all 3 methods are at least of the same order as those discharged by the rivers (Fig. 6). In estimating

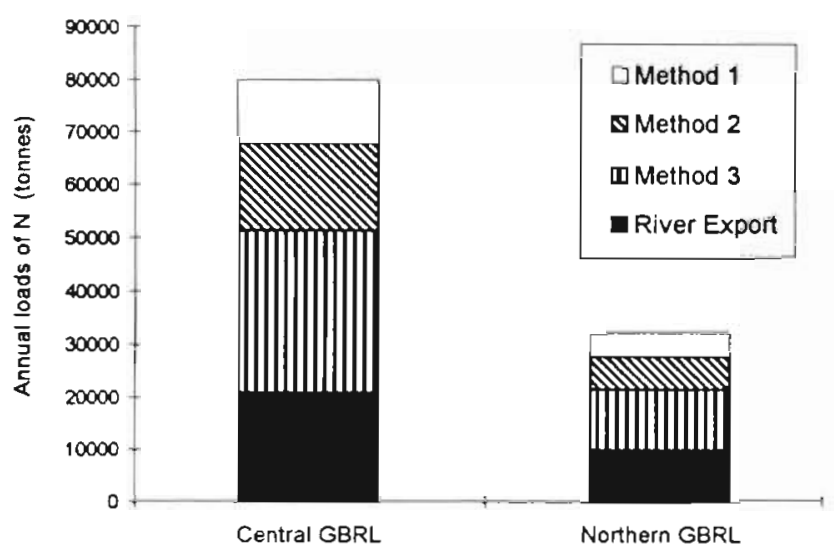

Fig. 6. Comparison of the estimated loads of nitrogen (N) introduced to the Central and Northern GBRL via river discharge with those from Trichodesmium spp. using Methods 1 to 3

the loads it was assumed that: (1) the active growth region for the Trichodesmium is $340 \mathrm{~km}$ long and $60 \mathrm{~km}$ wide in the Central GBRL; (2) the active growth region is $230 \mathrm{~km}$ long and $45 \mathrm{~km}$ in the Northern GBRL; and (3) the amount of $\mathrm{N}$ fixed per $\mathrm{km}^{2}$ varies linearly over the Northern GBRL from that calculated for the Central GBRL to that calculated for the Low Isles region. The river loads from the Central catchments (from Fitzroy to Herbert) and the Northern catchments (from Tully-Murray to Mossman-Daintree) are taken from Moss et al. (1992).

As noted above, the total $\mathrm{N}$ load introduced by Trichodesmium is probably best estimated by adding the loads obtained from Methods 2 and 3 and part of that from Method 1. If this is done, then the estimated loads of $\mathrm{N}$ introduced by Trichodesmium dwarf the loads from riverine export.

Acknowledgements. The field and laboratory assistance provided by Kate Hobson at Low Isles and that by Graham Grant in Townsville is greatly appreciated. Financial assistance provided by the Department of Chemical Engineering for purchase of the portable GC/PID and by the University of Queensland through the ESG scheme was indispensable for the completion of this work. Transportation, field and logistics support by Quicksilver Connections, Reefbiosearch and Marine Parks rangers (Queensland Department of Environment) is also greatly appreciated.

\section{LITERATURE CITED}

Bell PRF (1991) Status of eutrophication in the Great Barrier Reef lagoon. Mar Pollut Bull 23:89-93

Bell PRF (1992) Eutrophication and coral reefs - some examples in the Great Barrier Reef lagoon. Water Res 26(5): 553-568

Bell PRF. Elmetri I (1995) Ecological indicators of large scale eutrophication in the Great Barrier Reef (GBR) Lagoon. Ambio 24:4:208-215 
Bell PRF, Elmetri I, Li T, O'Neil JM (1993) Field measurements of nitrogen fixation rates of Trichodesmium spp. in the Great Barrier Reef Lagoon. Importance to the nitrogen budget of the Great Barrier Reef lagoon. Aust Coral Reef Soc Nat Conf, University of Queensland, Brisbane (Abstract)

Borstad LE (1978) A qualitative and quantitative examination of bacteria associated with Trichodesmium (cyanobacteria) species near Barbados. MSc thesis, Dept Microbiology, McGill University, Montreal

Brodie JE, Furnas MJ, Steven ADL, Trott LA, Pantus F, Wright M (1997) Monitoring chlorophyll in the Great Barrier Reef Lagoon: trends and variability. Proc 8th Int Coral Reef Symp, Smithsonian Tropical Research Inst, Balboa 1: $797-802$

Bryceson I, Fay P (1981) Nitrogen fixation in Oscillatoria (Trichodesmium) erythraea in relation to bundle formation and trichome differentiation. Mar Biol 61:159-166

Capone DG (1993) Determination of nitrogenase activity in aquatic samples using the acetylene reduction procedure In: Kemp PF et al. (eds) Handbook of methods in aquatic microbial ecology. Lewis Publishers, New York, p 621-631

Carpenter EJ, Capone DG (1992) Nitrogen fixation in Trichodesmium blooms. In: Carpenter EJ, Capone DG, Rueter JG (eds) Marine pelagic cyanobacteria. NATO ASI Series, Vol 362. Kluwer Academic Publishers, Dordrecht, p 211-215

Carpenter EJ, McCarthy JJ (1975) Nitrogen fixation and uptake of combined nitrogenous nutrients by Oscillatoria (Trichodesmium) thiebautii in the western Sargasso Sea. Limnol Oceanogr 20(3):389-401

Carpenter EJ, Price CC (1976) Marine Oscillatoria (Trichodesmium): explanation for aerobic nitrogen fixation without heterocysts. Science 191:1278-1280

Carpenter EJ, Price CC (1977) Nitrogen fixation, distribution, and production of Oscillatoria (Trichodesmium) spp. in the Western Sargasso and Caribbean Seas. Limnol Oceanogr 22(1):60-72

Cosser P (1987) Phosphorus loading to the Northern Great Barrier Reef from mainland runoff. In: Baldwin CL (ed) Proceedings of Workshop on Nutrients in the Great Barrier Reef Region. Great Barrier Reef Marine Park Authority, Townsville, p 39-43

Elmetri I (1993) Usefulness of the 1928-29 phosphate and micro-phytoplankton data for low isles as a baseline for eutrophication in the Great Barrier Reef Lagoon. MSc thesis, University of Queensland, Brisbane

Endean R (1976) Chap 7. Destruction and recovery of coral reef communities. In: Jones OA, Endean $R$ (eds) Biology and geology of coral reefs, VoI III, Biology 2. Academic Press, London, p 215-254

Furnas M, Mitchell AW, Skuza M (1995) Nitrogen and phosphorus budgets for the Central Great Barrier Reef shelf. Research Report No 36, Great Barrier Reef Marine Park Authority, Townsville

Editorial responsibility: Otto Kinne (Editor), Oldendorf/Luhe, Germany
Furnas M, Mitchell AW, Skuza M (1997) Shelf-scale nitrogen and phosphorus budgets for the Central Great Barrier Reef. Proc 8th Int Coral Reef Symp، Smithsonian Tropical Research Inst, Balboa 1:809-814

Goering JJ, Dugdale R, Menzel DW (1966) Estimates of in situ rates of nitrogen uptake by Trichodesmium sp. in the tropical Atlantic Ocean. Limnol Oceanogr 11:614-620

Howarth RW, Marino R, Cole JJ (1988) Nitrogen fixation in freshwater, estuarine and marine ecosystems 2. Biogeochemical controls. Limnol Oceanogr 33:688-701

Jones GB (1987) Nutrient input in Cleveland Bay. In: Baldwin CL (ed) Proceedings of Workshop on Nutrients in the Great Barrier Reef Region. GBRMPA, Townsville, p $153-160$

Jones GB (1992) Effect of Trichodesmium blooms on water quality in the Great Barrier Reef Lagoon. In: Carpenter EJ, Capone DG, Rueter JG (eds) Marine pelagic cyanobacteria. NATO ASI Series, Vol 362. Kluwer Academic Publishers, Dordrecht, p 273-287

Mague TH, Weare NM, Holm-Hansen O (1974) Nitrogen fixation in the north Pacific Ocean. Mar Biol 24:109-119

Marshall SM (1933) Great Barrier Reef expedition, 1928-29. Scientific reports, Vol II. British Museum (Nat History), London, p 111-155

Moss AJ, Rayment GE, Reilly N, Best EK (1992) A preliminary assessment of sediment and nutrient exports from Queensland coastal catchments. Report of Queensland Government, Department of Environment and Heritage and Department of Primary Industries, Brisbane

Ohki K, Fujita Y (1982) Laboratory culture of the pelagic bluegreen alga Trichodesmium thiebautii; conditions for unialgal culture. Mar Ecol Prog Ser 7:185-190

Orr AP (1933) Great Barrier Reef expedition, 1928-29. Scientific Reports, Vol II. British Museum (Nat History), London, p $37-85$

Revelante N, Gilmartin M (1982) Dynamics of phytoplankton in the Great Barrier Reef lagoon. J Plankton Res 4(1): $47-76$

Rueter JG (1988) Iron stimulation of photosynthesis and nitrogen fixation in Anabaena 7120 and Trichodesmium. J Phycol 24:249-254

Saino T, Hattori (1982) Aerobic nitrogen fixation by the marine non-heterocystous cyanobacterium Trichodesmium (Oscillatoria) spp.: its protective mechanism against oxygen. Mar Biol 70:251-254

Stewart WDP, Alexander GA (1971) Phosphorus availability and nitrogenase activity in aquatic blue-green algae. Freshw Biol 1:389-404

Yentsch CM, Yentsch CS, Perras JP (1972) Alkaline phosphatase activity in the tropical marine blue-green alga, Oscillatoria erythraea ('Trichodesmium'). Limnol Oceanogr 17 . $772-774$

Yentsch CS (1963) Primary production. Oceanogr Mar Biol Annu Rev 1:157-175

Submitted: May 8, 1998; Accepted: March 16, 1999

Proofs received from author(s): August 23, 1999 